\title{
Implication of emotions in the educational field: EEQ and ecq validation
}

\section{Implicación de las emociones en el ámbito educativo: Validación eeq y ECQ}

\author{
DOI: $10.46932 / s f j d v 3 n 1-070$
}

Received in: Jan 30st, 2021

Accepted in: Feb 1th, 2022

\author{
Jose María Rabal Alonso \\ Professor ISEN Centro Universitario \\ Universidad de Murcia \\ Calle Campus Universitario, 12, 30100 Murcia \\ E-mail: josemaria.rabal@um.es \\ María Ibañez Arroniz \\ Graduada en Educación Primaria. Mención NEAE \\ RG Formación \\ Calle Rosalía de Castro, 44, 30107 Murcia
}

\begin{abstract}
The article that is presented below shows a detailed investigation about the relationship between competence in emotional education and the educational style - from both agents, teacher and studentOnce a thorough bibliographic search was carried out, a series of unknowns were compiled that, not only as researchers but also as teachers, we were committed to offering the scientific community a tool that not only offered ease of completion appropriate for use in mass but, in addition, it was reliable and easy to use, so that experimental death is minimized as much as possible. To do this, two questionnaires (EEQ and ECQ) were prepared, which underwent an exhaustive review by a committee of experts.
\end{abstract}

Keywords: questionnaire, rubric, evaluation, emotions, educational style, emotional competence.

\section{RESUMEN}

El artículo que se presenta a continuación muestra una investigación detallada sobre la relación entre la competencia en educación emocional y el estilo educativo -desde ambos agentes, profesor y alumno-. Una vez realizada una exhaustiva búsqueda bibliográfica, se recopilaron una serie de incógnitas que, no sólo como investigadores sino también como docentes, nos comprometieron a ofrecer a la comunidad científica una herramienta que no sólo ofreciera una facilidad de cumplimentación adecuada para su uso en masa sino que, además, fuera fiable y fácil de utilizar, de manera que se minimizara al máximo la muerte experimental. Para ello, se elaboraron dos cuestionarios (EEQ y ECQ), que fueron sometidos a una exhaustiva revisión por parte de un comité de expertos.

Palabras clave: cuestionario, rúbrica, evaluación, emociones, estilo educativo, competencia emocional.

\section{INTRODUCTION}

As part of a collective nucleus, we belong to a society in which the internal and different conditions of each one of us are extrapolated, we contribute and learn, that is what it means to show ourselves unique 
and different, but with links between us. Education in this case helps us to improve, to coincide and to show our differences making them unique.

That is why one of the objectives of education is to promote situations in which each individual starts from the differences we have in common, to start from the basis that a diversity present in life and in the classroom must be addressed.

The difficulty of the process implies not knowing what reality each one of us starts from. That is why there is an emphasis and progress towards an emotional education, one in which the student is not only educated, but also begins the path towards the unknown, to the student's ability, their motivation, their preferences and the feelings and emotions produced by the situation that is lived day by day outside and inside the classroom, that is why we seek the bases on which our students are based, which does not focus on mere learning, following Hume (1739), within the educational field we see an example of "psychological emotivism", which points out as an area in which the subject is inclined towards emotions, that is, what guides and leads us to make certain decisions for which they are considered correct and therefore we express them, whether or not they are reasonable.

Education as such has to guide us towards our own knowledge of what surrounds us, but starting from self-knowledge of ourselves in order to understand how we relate to the rest, acting according to what our mind and our emotions tell us, following Bisquerra (2011) we have to keep in mind that it is not only about expressing what we feel and live, but also about understanding it and educating for its application and understanding, that is why we focus on an education that shows us the knowledge of what we feel, to be able to extrapolate it to education, to the student's motivations and to their own capacity, stimulus and response.

Emotional education brings us closer to a reality, to an area that is in full development and is born with a social need to respond to feelings that are present in society, how they are shown and even normalized, coming to be stipulated as situations of completely normal, without analyzing what are the decisions we make and why we do it, among the great unknowns is the world of feelings and not giving today a correct answer to the basis of these behaviors, not knowing how to understand them leads to confusion and what Bisquerra (2016) calls "emotional illiteracy". Among the emotions that he classifies as the majority and best known negatively, we find fear, anxiety and anger, so that it is a priority to find the core of what leads us to feel this in order to continue with other tasks or activities. Therefore, we tell ourselves that we want to uproot them, but rather learn and live with them, understanding the reason for them and learning to regulate them, as such, education is a good instrument to promote this knowledge and exploration of oneself and the rest. 
But to know where we start from, we base ourselves on the description that Gómez et al (2000) shows us in relation to the principles on which emotional intelligence is based:

- Self-knowledge: it is the ability to detect our own strengths and weaknesses.

- Self-control: the ability to control behaviors such as impulsiveness, anger...

- Self-motivation: it is of intrinsic origin and it is about doing things by one's own decision, without expecting anything in return.

- Empathy: the ability we have to put ourselves in the place of others in different situations and try to understand how they feel.

- Social skills: This is the ability to relate to other people in an appropriate way showing communication skills.

- Assertiveness: ability based on your own defense of your ideas, respecting the opinion of the rest.

- Proactivity: this is a skill related to anticipating events and being consistent with our actions.

- Creativity: ability to conceive an idea from different perspectives, contribute new ones, improve the previous ones... We can identify three perspectives of the concept of "emotional intelligence": the "skill model" that focuses on the individual's ability to process emotional information and use it appropriately within the social environment"; the "trait model" focuses on behavioral dispositions and self-perceived abilities"; and the "mixed model" describes the combination of mental abilities, dispositions, and traits" (Mayer, Caruso, and Salovey , 2000, p. 268).

As far as the literature is concerned, we can find two great models about Emotional Intelligence; these are the mixed model and the skill model. The mixed model that has in turn been the most popular thanks to Goleman, in which social skills are combined with the individual's own personality (Goleman and Bar-On) and on the other hand we find the skill model, highlighting Mayer and Salovey (1990), in which we find a model where personality is not taken as a component in the regulation of emotions, but a series of skills typical of cognitive processes are taken into account to combine personality dimensions such as optimism and ability to "perceive, evaluate, express, manage, and self-regulate emotions in an intelligent way adapted to the achievement of well-being, based on social norms and ethical values" (García-Fernández and Giménez-Mas, 2010). At this point we will focus on the skill model, which is based on the individual's ability to regulate their own emotions and how to act in the face of different stimuli and know how to understand and act against them.

Today the position of Emotional Intelligence according to the model of Salovey and Mayer (1997) has been the most defended in the educational field, we can find the beginnings of emotional education as far as the educational field is concerned with the LOGSE, in its article first appears as one of the purposes of education is "the full development of the student's personality" (Law 1/1990, October 3) and 
in this we find the inclusion of education in values. In subsequent laws, the criteria for inclusion of emotional education is refined, in accordance with Organic Law 2/2006, of May 3, on Education, which is mentioned in the preamble: "it is about ensuring that all citizens reach the maximum possible development of all their capacities, individual and social, intellectual, cultural and emotional...

In the current educational law, Organic Law 8/2013, of December 9, for the improvement of educational quality, the concept of Emotional Intelligence in the educational field has not been deepened, but the previous proposal has been maintained, but As we can see, in addition to treating it as a crosscutting theme, this law includes a specific subject that addresses emotional education and can be taken as an alternative to the Religion subject, and this is about Social and Civic Values.

When talking about emotional intelligence, it is convenient to refer to Mayer and Salovey and their Model of Emotional Intelligence (1997). This model is based on four basic skills, which are the ability to perceive emotions, the ability to understand them, the ability to generate positive feelings or emotions, and the ability to regulate emotions.

- Emotional perception: according to Mayer and Salovey (1997) emotional perception is the ability to identify one's own emotions, as well as those of others.

- Emotional facilitation or assimilation: when we experience sensations or feelings, there are emotions that are ingrained in them. That is why this facilitation or emotional assimilation works on the ability to manage and take these emotions into account when we reason or when we solve problems. Good management of emotions when solving a problem implies better decision-making.

- Emotional understanding: emotional understanding is linked to the ability to know the reason for emotions, why they have been generated and the consequences they have on our subsequent actions.

- Emotional regulation: according to Mayer and Salovey (1997) this ability is the most complex of all, since it involves the regulation of one's own and others' emotions, moderating those emotions that are negative to give more weight or intensify positive emotions. To do this, a person must be open to feelings, both positive and negative, and then know how to discard them or take advantage of them.

\section{THEORETICAL FRAMEWORK}

\subsection{EMOTIONAL EDUCATION AND ITS COMPETENCIES}

According to Vivas (2003), Bisquerra defines emotional education as:

An educational process, continuous and permanent, which aims to enhance emotional development as an essential complement to cognitive development, both constituting the essential elements of the development of the integral personality. To this end, the development of 
knowledge and skills on emotions is proposed in order to enable the individual to better face the challenges that arise in daily life. The purpose of all this is to increase personal and social wellbeing. (Bisquerra, 2000, cited in Vivas 2003, p.3).

In the process of emotional education, Bisquerra (2011) highlights the presence of the contents of emotional education, in which topics are contemplated that the emotions that exist, at what moment we develop them, how they affect us in our day to day, etc. Within the contents of emotional education, emotional competences stand out, and within it other aspects of a more specific nature. These emotional competencies are what allow us to possess abilities for emotional expression, understanding and regulation.

According to Bisquerra and Pérez (2007), these skills can be grouped into five large blocks that deal with different aspects in relation to emotions. These blocks are: emotional awareness, emotional regulation, personal autonomy, interpersonal intelligence and life skills and well-being.

Within the concept of competence we can find knowing how to do, knowing how to be and learning to learn, within the broad concept of emotional competence we can identify five dimensions.

- Emotional awareness: it is the ability that certain people have to become aware, not only of their own emotions, but also of the emotions of others

- Emotional regulation: it involves emotional management or manipulation, that is, being able to operate with our emotions appropriately. It also means having the ability to create positive emotions in order to deal with negative stimuli.

- Emotional autonomy: constitutes a group of elements that are closely linked to personal selfmanagement, among these elements the following stand out: self-esteem, positive attitude towards life, responsibility, ability to critically analyze social norms, the ability to seek help and resources, as well as emotional self-efficacy.

- Social skills: refers to the ability to establish positive interpersonal relationships. For this, the person must have skills related to communication skills, the socio-emotional area, attitudes of respect and tolerance, among others.

- Life skills and well-being: they involve the ability to adopt attitudes or behaviors to be able to lead a successful life, facing and overcoming life's problems.

\subsection{NEED FOR EMOTIONAL EDUCATION AT SCHOOL}

Emotional education is considered a necessity when addressing certain social aspects, which are not addressed in ordinary academic areas. These aspects that occur in most people in society are anxiety, stress, depression, risk behaviors, etc. In all these named situations, emotions play a fundamental role, 
since they have been produced by poor management or lack of control over them. Being able to manage or regulate them is possible if timely education or training is carried out. In short, an emotional education.

Currently, in the school system, a series of competencies related to academic areas are prioritized, thus leaving aside emotional competencies that must also be acquired by students. The latter are more difficult to acquire, however, they will be more useful in real life than the former. For example, in a term a student can learn to solve equations of the second degree, but it is more difficult for him to acquire the competence of anger regulation in conflict situations. It is very likely that in real life the latter is more necessary than the former.

To teach emotional education to students, it is necessary to educate teachers and families emotionally in the first place. Once they have acquired the appropriate tools and the appropriate emotional competencies, they are in a better position to train students emotionally. It is also of vital importance that the interest in emotional education is not the work of several teachers, but that the work is relegated to the entire educational community.

According to González Cabello and Fernández Berrocal (2016), emotional education is accompanied by various benefits that make people who have the appropriate tools for managing emotions experience good functioning in interpersonal relationships, mental health, academic performance, among others. aspects.

- Mental health occurs more frequently in those people who have self-management of their emotions, since these people have fewer psychosomatic symptoms, anxiety, depression, etc. This ability to properly perceive, manage and understand one's own emotions and those of others acts as a protector in the lives of students, first in the school stage, and then in the stage of adolescence, in which aspects such as consumption legal (tobacco or alcohol) or illegal (cannabis or cocaine) drugs. Most people use drugs to change their emotional states. That is why emotional education develops a positive attitude in people, increasing their own and social well-being.

- Social relationships or social functioning are also improved, since low emotional intelligence causes aggressive behavior to appear. However, when students have adequate emotional intelligence, they are more prosocial people with quality interpersonal relationships.

- Intellectual and academic performance is closely linked to emotional intelligence, since emotionally intelligent students obtain better academic results. Those people who have control of their own emotions are able to give greater weight to the positive emotions they experience, thus channeling negative emotions. 
In this sense, Ibañez (2002) already announced the importance that the teaching-learning process — per se — had a relationship mode with imposing effects for the formation and learning by the students, not only in the personal field but, also, in the academic field, at all levels. In Ibanez's words, "the perception that students have of their interpersonal relationships with teachers would be what has the greatest impact on them, and not the content or subject of study".

Delving analytically into the relationship that emotions can have — and have - in the educational field, we find studies such as the one carried out by Trujillo, Ceballos, Trujillo and Moral (2020) in which they reflect, on the one hand, regarding the importance given to emotions in the classroom:

The majority of teachers $(82 \%)$ positively value work with emotions, since $48 \%$ attach great importance to emotions in the classroom and $34 \%$ quite a bit, while, on the other hand, $14 \%$ and $3 \%$ think that the incorporation of emotional education in their teaching performance is somewhat and not very important, respectively. As for adding emotional competence as The role of emotions in the Early Childhood Education classroom 236 key competence for boys and girls in the $21 \mathrm{st}$ century, $81 \%$ are in favor of doing so. Specifically, $29 \%$ think that it is quite necessary and $52 \%$ that it is very necessary, while $16 \%$ believe that it is somewhat, and the remaining $3 \%$ think that it is little or not at all. (p.238)

Although it is true, certain training gaps are appreciated, as reflected in the same work by Trujillo, Ceballos, Trujillo and Moral (2020) previously presented.

\begin{abstract}
According to the results, almost $80 \%$ of the participating teachers evaluate their training in emotional education as poor: $27 \%$ consider that they have received no training at all, $29 \%$ some and $23 \%$ little. Only $18 \%$ consider that they have had enough training and $3 \%$ a lot. In the same vein, most of the teachers $(83 \%)$ believe it is necessary to have training in emotional education during the career of teacher in early childhood education (54\% a lot and $29 \%$ quite a lot). Only $15 \%$ see it somewhat and $2 \%$ seldom need it. (p.239)
\end{abstract}

\title{
2.3 TEACHING STYLES IN EDUCATION
}

Throughout this section, we are going to focus on presenting the different existing teaching styles, in addition to highlighting their implication in the socio-emotional development of students.

Teaching styles are modes, forms, adoptions or particular and characteristic ways of thinking about the educational process and of assuming the teaching-learning process in a specific context that are manifested in attitudes, behaviors, actions, procedures, activities that are put into play. in teaching praxis based on aspects such as: classroom environment, relationship, interaction, socialization and orientation of students; organization, preparation or planning of the academic activity; presentation of information, teaching methods, direction, management and control of the teaching-learning process, direction of tasks and evaluation. These are the product of assumptions, principles, beliefs, ideas and concepts underlying pedagogical practices that may be more or less conscious (Rendón, 2010:7). 
In this sense, the author defines teaching styles taking into account different variables related to personality, behavior, knowledge and the implicit or explicit conceptions that the teacher has about teaching and learning or the combination between them. Also, this definition leads us to reflect on the educational process, how the different actions of teachers, that is, their teaching styles, can affect the socio-emotional education of students.

For this research, following Rendón (2013), the two teaching styles that appear most frequently in the specialized literature were taken into account:

- Mediational teaching style: provides security and confidence in the classroom. He manages a close relationship with his students, generates a space for dialogue, takes advantage of his students' ideas for the construction of knowledge, assumes his students' mistakes as learning options, motivates cooperative and group work for learning, promotes the exchange and participation of his students, part of the concerns of his students, for the development of topics in class, he prefers that the questions formulated by the students be discussed during his intervention.

- Teaching style Master: promotes little interaction in the classroom, establishes a strict academic relationship with students, shows little disposition for dialogue, imposes his ideas over the approaches offered by his students, considers students' mistakes as lack of knowledge, promotes rote learning of data, prefers silence and listens attentively during his classes, attends to the concerns of his students only at the times he considers appropriate, prefers that the questions be formulated at the end of his intervention.

Likewise, following Arís Redó (2010), the teaching style that each teacher assumes in the educational process must be strengthened, so that they make their classes dynamic spaces for knowledge acquisition, in addition to promoting socio-emotional competence in the classroom. Thus, students will be able to adequately manage and control emotions, in addition to establishing healthy and competent relationships.

WhatFinally, we could mention Francisco Mora, an illustrious Doctor of Neuroscience and Medicine who, in an interview conducted by the magazine Educación 3.0, stated:

It is not about encouraging emotions in the classroom, but about teaching with emotion, which means making what is taught curious. Curiosity arouses the attention of those who listen and learn automatically and with this, it is obvious, they learn better. Nothing can be learned without alert, sustained, conscious attention. And nothing arouses more attention than what is different and curious. A monotonous, boring or repetitive teacher is a clear example of the value of emotion in those who teach. An excellent teacher is one who is capable of turning any thing or concept, even a mathematical one, that seems 'dull', into something always interesting. 


\subsubsection{Learning styles}

Honey and Mumford (1986) make a classification of four main types of learning styles in which we find:

- Active Style: They are characterized by being enthusiastic, improvisers and risk takers. They are drawn to new experiences and enthusiastic about novelty. These people are surrounded by people, but they are the center of activities.

- Reflective Style: These people are characterized by being observant, analytical and cautious. They learn by reflecting on the events that occur. They tend to reach conclusions or act after having made a detailed analysis.

- Theoretical Style: People within this group are characterized by being logical and rational. They integrate the observations they have made into complex and coherent theories, that is, they are interested in learning about theories that support what we say. These people think sequentially and are oblivious to subjective judgments.

- Pragmatic Style: As its name suggests, these people are characterized by wanting to put into practice what they have learned to know if that learning will be useful in their day to day. When solving a problem, they tend to make quick decisions.

\section{PROCESS OF CREATION, CONFORMATION AND VALIDATION}

To provide an individualized education adjusted to the abilities and needs of the students, it is necessary to use techniques and methods of knowledge and inquiry. In this sense, one of the most useful instruments — without a doubt — is the questionnaire (Rabal, Guirao and Martínez, 2020), being the ease of reproduction and use, both of the tool per se and of the results of the data obtained its greatest benefits.

As mentioned, it is not a mere proposal, but what is presented in this research is a questionnaire, with detailed theoretical support, as well as subsequent validation by experts. The validation process of the questionnaires consisted of distributing them to active professionals, both in Early Childhood Education and Primary Education and in university education - being able, thanks to such a wide range, to extrapolate the results to secondary or high school students-. All of them were asked to write down the time to complete these - questionnaires_-, in order to verify that the completion was done in a short space of time.

Delving into the procedure object of the conformation of this questionnaire, following authors such as Rabal, Clemente, Casanova \& González (2020), it was conceived through a double aspect. The first aspect to consider was the detailed bibliographical analysis that was carried out before the variables related to emotions, and their possible relationship with the educational field, once this was completed, 
those of greater relevance were obtained, among which some of the most important are included in the present study. The second main key on which the validity and significance of these questionnaires are based - present in ANNEXES — was the indispensable participation of different experts in the field. These experts ranged from university teaching, Primary Education,

\section{CONCLUSIONS AND IMPLICATIONS}

The inclusion and exclusion criteria for each item followed a methodology similar to that already presented by Rabal, Guirao and Martínez (2020), as well as in Rabal, Clemente, Casanova \& González (2020), consisting of establishing a consonance of at least three of the five judges. For those scores —out of five points - of three or less in two or more of the judges, the subject item was reviewed or discarded. This produced a total of eight discards, as well as the reformulation of four items, counting them together from the two questionnaires.

The result of this process is the formation of a highly suitable tool, due to its short completion time, but, above all, due to the relevance and reliability of the data obtained.

\section{LIMITATIONS}

One of the most important issues when presenting a research work is to carry out a final process of feedback and meditation in order to collect the difficulties that occurred during the conformation of the study in order to know the limitations of — in our case — a questionnaire that will serve — no doubt — for future investigations, the results of which must undoubtedly be truthful and reliable.

In this sense, the main limitation that we can consider, especially since it is a questionnaire, is that the data obtained does not confer the aforementioned veracity or reliability to the data obtained. There is no doubt that any questionnaire based on a Likert-type scale can present a certain margin of reliability in the answers. To avoid this event, as well as to detect possible fraud in the answers - at the cost of experimental death - we introduce different questions, with different structures, for the same variable, which, when put into a data program (SPSS) will do a good job, and in an easy way, the veracity and reliability of each respondent, in addition to being able to extract results that are as accurate and reliable as possible. In addition to this, the items present in all cases clear, concise and concrete statements. Nonetheless, and in view of the limitations inherent to any questionnaire, a complementary measure could be implemented, namely, conducting interviews that allow deepening into qualitative aspects of the research. Finally, the fact of presenting the biased questionnaires gives the possibility of adjusting them to the approach of the object study, in addition to expanding the possibilities of study including contrasts 
between both results obtained, as is the case of studies such as the one carried out by Trujillo, Ceballos , Trujillo and Morales (2020). 


\section{REFERENCES}

Bisquerra, R. (2016). Emotional education. Unpublished document prepared for the I Conference of the Master in Conflict Resolution in the Classroom.

Bisquerra, R. (Coord.). (2011). Emotional education. Proposals for educators and families. Bilbao: Desclee de Brower.

HUME, D. (1739). Treatise on Human Nature, Vol. II. Madrid: Espasa Calpe, 1923

Rendon, M. (2010). Teaching styles at the University of Antioquia (first phase Faculty of Education). $\begin{array}{llll}\text { Unipluriversity } & \text { Magazine } & 10 & \text { Recovered }\end{array}$ fromhttp://aprendeenlinea.udea.edu.co/revistas/index.php/unip/article/viewFile/7198/6651

Rendon, M. (2013). Final report of the research The education of socio-emotional competence and teaching styles in Secondary Education of the Municipality of Caucasia. Medellin, Colombia: University of Antioquia.

Aris Redó, N. (2010). Emotional education and school communication. Vivat Academy, (113). Recovered fromhttp://www.vivatacademia.net/index.php/vivat/article/view/949/821

Trujillo González, E., Ceballos Vacas, EM, Trujillo González, MC \& Moral Lorenzo, C. (2020). The role of emotions in the early childhood education classroom. Faculty. Journal of Curriculum and Teacher Training, 24(1), 226-244.

Ibáñez, Nolfa THE EMOTIONS IN THE CLASSROOM Pedagogical Studies, no. 28, 2002, p. 31-45 Austral University of Chile Valdivia, Chile

Rabal Alonso, JM; Guirao Carpes, Mª C. And Martínez García, V. (2020). Validation of questionnaires on the use of tics in the classroom: ITICA and TICAMA. Brazilian Journal Of Development, 6 (3).

Rabal Alonso, JM; Clemente Flores, CM; Casanova Murcia, C. \& González Romero, M. (2020). Importance of the treatment of death in the educational field: ICES questionnaire validation.Brazilian Journal Of Development, 6 (4). 


\section{ANNEXES}

\section{ANNEX I}

The purpose of this questionnaire is to determine the degree of emotional competence in the educational field.

We would like to count on your collaboration. The questionnaire is ANONYMOUS, so please answer the questions as honestly as possible — there are no right or wrong answers. The duration of this questionnaire will be between 10 and 15 minutes.

THANK YOU FOR YOUR COLLABORATION

\begin{tabular}{|l|l|l|l|}
\hline one & two & $\mathbf{3}$ & $\mathbf{4}$ \\
\hline Never & Sometimes & Often & Forever \\
\hline
\end{tabular}

\begin{tabular}{|c|c|c|c|c|}
\hline EMOTIONAL COMPETENCE QUESTIONNAIRE: ECQ & one & two & 3 & 4 \\
\hline \multicolumn{5}{|l|}{ EMOTIONAL COMPETENCE } \\
\hline \multicolumn{5}{|l|}{$\begin{array}{l}\text { 1. I have received previous training about what multiple } \\
\text { intelligences are. }\end{array}$} \\
\hline \multicolumn{5}{|l|}{$\begin{array}{l}\text { two.I have received previous training about what emotional } \\
\text { education is. }\end{array}$} \\
\hline \multicolumn{5}{|l|}{$\begin{array}{l}\text { 3.I have received previous training on how to teach emotional } \\
\text { education. }\end{array}$} \\
\hline \multicolumn{5}{|l|}{$\begin{array}{l}\text { 4. I have promoted activities in the classroom to identify and } \\
\text { manage emotions. }\end{array}$} \\
\hline \multicolumn{5}{|l|}{$\begin{array}{l}\text { 5. I am up to date with scientific news on emotional education } \\
\text { and its transversality. }\end{array}$} \\
\hline \multicolumn{5}{|l|}{$\begin{array}{l}\text { 6. Many times I don't know how to deal with conflicts in the } \\
\text { classroom. }\end{array}$} \\
\hline \multicolumn{5}{|l|}{ 7.There are students who, sometimes, unnerve me. } \\
\hline \multicolumn{5}{|l|}{$\begin{array}{l}\text { 8.I take into consideration external factors - family situation, } \\
\text { personal of my students - in order to address the emotions of } \\
\text { my students. }\end{array}$} \\
\hline \multicolumn{5}{|l|}{ 9.I am objective in the emotional treatment of my students. } \\
\hline \multicolumn{5}{|l|}{$\begin{array}{l}\text { 10.I have self-awareness of basic emotions -sadness, fear, joy, } \\
\text { anger, surprise- }\end{array}$} \\
\hline \multicolumn{5}{|l|}{$\begin{array}{l}\text { eleven.I know disorders related to the inability to express } \\
\text { emotions. }\end{array}$} \\
\hline \multicolumn{5}{|l|}{$\begin{array}{l}\text { 12. I believe that emotional education should be worked only } \\
\text { through the school. }\end{array}$} \\
\hline \multicolumn{5}{|l|}{$\begin{array}{l}\text { 13. I believe that emotional education is worked on enough in } \\
\text { the classroom. }\end{array}$} \\
\hline \multicolumn{5}{|l|}{$\begin{array}{l}\text { 14. I am aware that the same situation can trigger several } \\
\text { emotions. }\end{array}$} \\
\hline $\begin{array}{l}\text { fifteen. I believe that emotional education is linked to an } \\
\text { improvement in interpersonal relationships. }\end{array}$ & & & & \\
\hline
\end{tabular}




\section{ANNEX II}

The ultimate goal of this questionnaire is to find out the educational style used, in order to be able to establish a relationship between it and the emotional component.

We would like to count on your collaboration. The questionnaire is ANONYMOUS, so please answer the questions as honestly as possible — there are no right or wrong answers. The duration of this questionnaire will be between 10 and 15 minutes.

THANK YOU FOR YOUR COLLABORATION

\begin{tabular}{|l|l|l|l|}
\hline one & two & $\mathbf{3}$ & $\mathbf{4}$ \\
\hline Never & Sometimes & Often & Forever \\
\hline
\end{tabular}

\begin{tabular}{|l|l|l|l|l|}
\hline $\begin{array}{l}\text { EMOTIONAL EDUCATION QUESTIONNAIRE: } \\
\text { EEQ }\end{array}$ & one & two & $\mathbf{3}$ \\
\hline EDUCATIONAL STYLE & & & \\
\hline 1. I work on emotions every day in the classroom. & & & \\
\hline $\begin{array}{l}\text { 2. I take advantage of circumstances that occur on a day- } \\
\text { to-day basis with students to work on emotions. }\end{array}$ & & & \\
\hline 3. I invite my students to express their emotions & & & \\
\hline 4. I try to get my students to put words to what they feel. & & & \\
\hline $\begin{array}{l}\text { 5. Among the main behavior modification techniques I } \\
\text { use punishment. }\end{array}$ & & & \\
\hline $\begin{array}{l}\text { 6. I consider myself demanding in relation to the results } \\
\text { I hope to obtain from the students. }\end{array}$ & & & \\
\hline 7. I have the means to resolve a conflict peacefully & & & \\
\hline $\begin{array}{l}\text { 8. We establish among all (tutor and students) the rules } \\
\text { of the class. }\end{array}$ & & & \\
\hline 9. I help my students make good decisions. & & & \\
\hline $\begin{array}{l}\text { 10. Faced with a classroom situation that cannot be } \\
\text { managed or controlled, I ask for help or advice. }\end{array}$ & & & \\
\hline $\begin{array}{l}\text { 1. I carry out guidelines or strategies in the classroom } \\
\text { that enable an adequate climate in the classroom. }\end{array}$ & & & \\
\hline $\begin{array}{l}\text { 12. I prepare my program based on those ideas that } \\
\text { motivate my students. }\end{array}$ & & & \\
\hline $\begin{array}{l}\text { 13. In class I carry out a methodology that favors the } \\
\text { development of emotional competencies. }\end{array}$ & & & \\
\hline $\begin{array}{l}\text { 14. I consider it more important that students learn } \\
\text { Mathematics or Language than that they learn how to } \\
\text { manage their emotions. }\end{array}$ & & & \\
\hline $\begin{array}{l}\text { 15. In class I encourage listening and the ability to } \\
\text { empathize in order to promote prosocial attitudes among } \\
\text { students. }\end{array}$ & & & & \\
\hline
\end{tabular}

